How to cite

Kasim, M., \& Ahmad, N. S. (2019). Ketahanan diri akademik dalam kalangan murid daripada ibu bapa bercerai. Malaysian Journal of Learning and Instruction, 16(1), 233-256.

\title{
KETAHANAN DIRI AKADEMIK DALAM KALANGAN MURID DARIPADA IBU BAPA BERCERAI
}

\section{ACADEMIC RESILIENCE AMONG STUDENT FROM DIVORCED PARENTS}

\author{
${ }^{1}$ Marini Kasim \& ${ }^{2}$ Nor Shafrin Ahmad \\ ${ }^{1}$ Pusat Pengajian Pendidikan dan Bahasa Moden, \\ Universiti Utara Malaysia, Malaysia \\ ${ }^{2}$ Pusat Pengajian Ilmu Pendidikan, Universiti Sains Malaysia \\ ${ }^{\text {I} C o r r e s p o n d i n g ~ a u t h o r: ~ m a r i n i @ u u m . e d u . m y ~}$
}

Received:19 September 2018 Revised: 20 February 2019 Accepted: 26 March 2019

\begin{abstract}
ABSTRAK
Tujuan - Kajian ini dilakukan untuk menentukan pengaruh faktor pelindung dan kekuatan dalaman terhadap ketahanan diri akademik dalam kalangan murid dari ibu bapa bercerai. Kajian ini juga bertujuan untuk mengenal pasti dimensi faktor pelindung dan kekuatan dalaman yang menjadi peramal yang berkesan bagi menentukan ketahanan diri akademik murid dari latar belakang ibu bapa yang bercerai.
\end{abstract}

Metodologi - Kaedah penyelidikan gabungan (mixed-methods) antara kuantitatif dan kualitatif digunakan melalui pengumpulan data secara soal selidik dan temu bual ke atas murid tingkatan empat dari sekolah-sekolah yang terpilih di Kedah. Responden bagi soal selidik untuk kaedah kuantitatif terdiri daripada 46 orang murid tingkatan empat dari 19 buah sekolah di Kedah yang telah dikenal pasti sebagai murid dari keluarga yang ibubapa bercerai. Seterusnya untuk kaedah kualitatif pula seramai lima orang murid telah dipilih secara persampelan bertujuan mengikut keperluan kajian untuk 
ditemu bual berdasarkan status perkahwinan ibu bapa (bercerai). Kaedah triangulation digunakan untuk melihat kesepadanan antara data kuantitatif dan kualitatif agar dapatan kajian adalah lebih komprehensif.

Dapatan - Dapatan kajian menunjukkan tahap faktor pelindung, kekuatan dalaman dan ketahanan diri murid adalah tinggi. Hasil temu bual menunjukkan faktor pelindung memainkan peranan yang lebih bagi meningkatkan ketahanan diri berbanding kekuatan dalaman. Semua murid yang ditemu bual mempunyai hubungan yang rapat dan menghargai perhubungan erat sama ada dalam kalangan adik beradik, kawan-kawan ataupun guru di sekolah.

Signifikan - Hasil kajian membuktikan terdapat keperluan kritikal terutamanya bagi guru untuk memahami faktor-faktor pelindung yang mampu meningkatkan tumpuan murid semasa proses pengajaran dan pembelajaran berlangsung serta ketahanan diri murid secara keseluruhannya dalam bidang akademik. Gabungan dapatan secara kuantitatif dan kualitatif telah menyediakan maklumat yang boleh digunapakai oleh guru-guru sebagai garis panduan dalam mengenal pasti langkah-langkah awal yang perlu diambil untuk menangani kesediaan murid untuk belajar jika berlaku perceraian.

Kata kunci: Ketahanan diri, faktor pelindung, kekuatan dalaman, perceraian, Teori Ekologi Bronfenbrenner, Model Ketahanan Diri Richardson.

\begin{abstract}
Objectives - This study was conducted to determine the influence of the protective factor and internal strength on academic resilience among students of divorced parents. The study also aims to identify the dimensions of protective factors and internal strengths that become the predictors of student's academic resilience of divorced parents.
\end{abstract}

Methodology - Mixed methods approach of quantitative and qualitative methods were administrated through questionnaires and interviews with form four students from selected schools in Kedah. The respondents for quantitative methods consist of 46 form four students who have been selected through systematic sampling from 
19 schools in Kedah. As for the qualitative method, 5 pupils were selected using purposive sampling. The interview questions were designed to further study the role, the influence of protective factors and internal strength in improving students' academic resilience who are from the divorced parents. The triangulation method is used to see the equivalence between quantitative and qualitative data so that the findings are more comprehensive.

Findings - Overall the findings demonstrate that the variables of protective factors, internal strength and resilience is at a high level. The interview results show that the protective factors play a greater role in improving academic resilience than internal strength. All respondents found close relationships and appreciates the close relationship between siblings, friends or teachers at school.

Significant - The findings indicate that there is a critical need especially for teachers to understand the protective factors that can enhance the focus of the students during the teaching and learning process as well as the students' overall resilience in the academic field. The combined quantitative and qualitative findings have provided information that teachers can use as a guideline in identifying the initial steps that need to be taken to address students' readiness to learn in the event of divorce.

Keywords: Resilience, protective factor, internal strength, divorce, Teori Ekologi Bronfenbrenner, Richardson Resilence Model.

\section{PENGENALAN}

Ketahanan diri secara amnya menerangkan kemampuan seseorang individu untuk menghadapi tekanan atau trauma dalam kehidupan dan berjaya menyesuaikan diri secara positif dengan persekitaran dan cabaran yang dihadapi. Individu yang mempunyai ketahanan diri mampu mengatasi tekanan sehingga menjadi individu yang lebih baik dari sebelumnya. Ketahanan diri membezakan antara individu yang mampu bertahan walaupun terpaksa mengharungi liku dan cabaran dalam hidup dengan individu yang tidak mampu bertahan malah mengalami kehidupan yang porak peranda. Snyder dan Lopez (2007) menyatakan fenomena ketahanan diri adalah salah satu aspek dalam psikologi positif iaitu pendekatan saintifik yang mengupas kekuatan dan nilai-nilai positif manusia. Seseorang 
individu hanya akan dikategorikan mempunyai ketahanan diri sehingga mereka diuji dengan risiko atau ancaman (Snyder \& Lopez, 2007). Kajian terkini berkaitan ketahanan diri banyak menumpukan perhatian kepada kepelbagaian kaedah penyesuaian dan perubahan serta interaksi yang berlaku antara kanak-kanak dengan keluarga dan faktor sekeliling mereka (Snyder \& Lopez, 2007; Sanders \& Jordan, 2013).

Dalam konteks akademik, ketahanan diri merujuk kepada kemampuan murid untuk mengatasi keadaan yang sukar atau kronik yang menjadi ancaman utama proses pembelajaran (Martin \& Marsh, 2009) dan kecenderungan untuk mencapai kejayaan di sekolah dan juga kejayaan dalam kehidupan walau pun berada dalam persekitaran yang mencabar (Wang, Haertal, Walberg 1994, 1998). Keadaan yang sukar dan menjadi ancaman kepada proses pembelajaran dan tekanan dalam kehidupan murid berpunca dari pelbagai aspek seperti faktor ekonomi, latar belakang keluarga, sosial persekitaran dan masalah kekeluargaan seperti perceraian ibu bapa (Amato, 2001; Amato \& Previti, 2003; Kelly \& Emery, 2003). Ancaman atau tekanan hidup yang difokuskan dalam kajian ini ialah perceraian kedua ibu bapa. Kajian ini seterusnya mengenal pasti pengaruh faktor pelindung dan kekuatan dalaman yang membentuk ketahanan diri murid dari segi akademik; iaitu keupayaan murid untuk kekal menumpukan perhatian dalam pembelajaran walaupun berhadapan dengan kesan negatif perceraian tersebut. Kajian berkaitan ketahanan diri memerlukan penilaian ke atas kekuatan dalaman individu yang terbabit dan juga persekitaran yang mempengaruhinya. Kefahaman ke atas peribadi dan persekitaran individu tersebut diperlukan agar para guru memahami bahawa murid memerlukan proses penyesuaian pembelajaran yang berbeza ketika menangani risiko yang melanda (Masten \& Reed, 2002). Perbahasan dan perbincangan mengenai ketahanan diri wajar dilakukan serentak dengan faktor pelindung (protective factors) dan kriteria-kriteria penyesuaian yang positif dalam kalangan mereka yang terlibat (Snyder \& Lopez, 2007).

Kajian yang dijalankan ini mengkaji dari perspektif psikologi positif iaitu mengenal pasti faktor pelindung dan kekuatan dalaman yang dapat meningkatkan ketahanan diri akademik murid, seterusnya menyediakan maklumat tentang aspek penting dalam konteks akademik iaitu aspek ketahanan diri akademik yang kurang mendapat perhatian oleh para penyelidik di Malaysia. Secara spesifiknya, kajian ini akan melihat bagaimana faktor pelindung dan kekuatan 
dalaman yang mempengaruhi ketahanan diri akademik murid yang berasal dari ibu bapa bercerai.

Objektif kajian ini adalah seperti berikut:

i) Mengenal pasti tahap bagi faktor pelindung, kekuatan dalaman dan ketahanan diri akademik murid;

ii) Mengenal pasti secara lebih mendalam bagaimana faktor pelindung dan kekuatan dalaman memainkan peranan dalam meningkatkan ketahanan diri akademik murid.

\section{SOROTAN LITERATUR}

Sorotan literatur ini akan mengupas beberapa konsep penting yang berkaitan dengan kajian yang dijalankan iaitu konsep ketahanan diri, kekuatan dalaman dan faktor pelindung. Beberapa teori dan model yang berkaitan juga turut dibincangkan.

\section{Ketahanan Diri}

Ketahanan diri menggambarkan kekuatan, tenaga dan sifat tahan lasak (Greeff \& Van Der Merwe, 2004). Ketahanan diri seterusnya membawa maksud penyesuaian positif walaupun dilanda penderitaan di dalam hidup (Sameroff, 2006). Ini selari dengan apa yang diperkatakan oleh Ungar $(2005,2012)$, bahawa pembentukan ketahanan diri merupakan proses sistematik yang berlaku antara seseorang dengan persekitarannya.

Menurut Cabness (2003), ketahanan diri merujuk kepada situasi seseorang yang masih kompeten dan mampu bertahan atau berfungsi dengan sempurna walaupun dilanda ancaman dan tekanan dalam hidup. Richardson (2002) mendefinisikan ketahanan diri sebagai mengalami perkembangan hidup yang lebih baik walaupun dilanda gangguan dan ancaman dalam kehidupan mereka. Ketahanan diri dalam bidang akademik merujuk kepada kemampuan murid untuk mengatasi ancaman dan kesukaran kronik yang mengganggu proses pembelajaran dengan menunjukkan hasil yang memuaskan walaupun mendapat ancaman dari persekitarannya (Masten, 2001).

Dalam konteks persekolahan, menurut Azlina (2010) murid yang dikenal pasti mempunyai ketahanan diri akademik ialah murid yang 
berjaya menyesuaikan diri dengan keadaan hidup yang berisiko. Bagi kajian ini ancaman yang dimaksudkan ialah perceraian kedua ibu bapa, mana kala perkembangan hidup positif ialah kemampuan murid untuk tidak tercicir dari persekolahan dan masih bermotivasi untuk belajar walaupun berada dalam suasana yang tertekan dan mencabar akibat dari perceraian ibu bapa. Rasional pemilihan faktor perceraian sebagai ancaman dalam kajian ini adalah berdasarkan pernyataan iaitu selagi kadar perceraian terus meningkat, selagi itu anak-anak dari ibu bapa yang bercerai terdedah dengan risiko tinggi dari segi pencapaian akademik yang rendah, perhubungan sosial yang bermasalah, penyesuaian psikologi yang sukar dan juga masalah tingkah laku dan sikap (Amato \& Keith, 1991, 2014).

Terdapat murid dari ibu bapa yang bercerai menunjukkan ketahanan diri dalam bidang akademik yang memuaskan berbanding dengan murid lain yang menerima nasib yang sama. Oleh itu dengan mengenal pasti dan memahami faktor-faktor pelindung yang mampu meningkatkan ketahanan diri akademik dalam kalangan mereka, secara tidak langsung akan membantu dalam usaha melaksanakan program intervensi akademik yang lebih berfokus dan bermakna ke atas murid lain yang senasib (Greeff \& Van Der Merwe, 2004).

Salah satu model yang sering dirujuk bagi menghuraikan konsep ketahanan diri adalah Model Ketahanan Diri oleh Richardson (2002). Berdasarkan model ini, seseorang itu akan mempunyai ketahanan diri setelah melalui dua perkara iaitu gangguan atau tekanan dalam hidup dan juga penyesuaian positif selepas melalui gangguan atau tekanan tersebut. Proses tersebut bermula di peringkat keseimbangan biopsikospiritual (tubuh badan, minda dan semangat), sehinggalah mereka dilanda masalah atau ancaman di dalam hidup. Di dalam keadaan bermasalah atau terancam individu akan bertindakbalas melalui salah satu dari empat cara iaitu menjadi lebih baik (mempunyai ketahanan diri), kembali ke keadaan keseimbangan, berubah menjadi lebih teruk atau menjadi tidak berfungsi. Walau bagaimanapun menurut Model Ketahanan Diri Richardson ini, tindakbalas yang ditunjukkan oleh individu yang terancam banyak bergantung kepada faktor pelindung yang terdapat di persekitaran individu tersebut. Penyesuaian yang dipamerkan sama ada penyesuaian positif atau negatif menggambarkan hasil dari pengaruh faktor pelindung yang diterima. Penyesuaian positif 
berlaku apabila individu menunjukkan ketahanan diri atau kembali ke keadaan asal, manakala penyesuaian negatif apabila individu menunjukkan kemerosotan dalam kualiti kehidupan atau terus menjadi tidak berfungsi.

\section{Kekuatan Dalaman}

Ketahanan diri sangat berkait rapat dengan kualiti ataupun kekuatan dalaman seseorang individu. Berdasarkan Resilience and Youth Development Module yang dibangunkan bersama oleh West Ed dan California Department of Education (CDE) (2000), terdapat enam dimensi faktor kekuatan dalaman yang menentukan ketahanan diri akademik seseorang individu. Enam dimensi tersebut ialah kerjasama dan komunikasi (cooperation and communication), empati, kemahiran menyelesaikan masalah (problem solving), efikasi kendiri (self-efficacy), kesedaran kendiri (self- awareness) dan matlamat serta aspirasi.

West Ed dan CDE (2000) menjelaskan bahawa murid yang mampu bekerjasama dan berkomunikasi dengan baik ialah individu yang mempunyai kompetensi sosial yang tinggi. Murid tersebut biasanya boleh bertukar-tukar pendapat dengan mudah dan fleksibel. Beliau juga mampu menyuarakan perasaan serta kehendak secara berkesan dengan pihak lain. Dari segi kemahiran menyelesaikan masalah pula, mereka melihat kepada kemampuan seseorang murid mencari penyelesaian secara unik ke atas setiap situasi yang dihadapi. Ianya merangkumi kemampuan merancang, berfikir secara kritikal dan kreatif, mampu menilai keadaan dari pelbagai perspektif sebelum membuat keputusan atau mengambil tindakan.

Empati pula merupakan kemampuan seseorang untuk memahami dan merasai pengalaman dan perasaan orang lain. Ciri personaliti sebegini merupakan ciri yang penting kerana mampu mewujudkan perasaan saling menghormati sesama manusia. Tanpa perasaan empati masalah berkaitan dengan keganasan seperti buli dan mencabul akan wujud berleluasa di sekolah. Situasi ini akan mempengaruhi pencapaian akademik murid-murid yang berada di dalam persekitaran sekolah tersebut. Seterusnya, model ini juga mengambilkira konsep efikasi kendiri iaitu merujuk kepada keinginan dan kepercayaan seseorang kepada kemampuan dan kuasa yang ada padanya untuk membuat sesuatu perubahan atau melaksanakan tugas yang diterima sebaik 
mungkin. Dalam persekitaran akademik, efikasi kendiri dinilai berdasarkan pencapaian akademik. Efikasi kendiri murid membawa maksud keyakinan murid ke atas kemampuan untuk melaksanakan tugas-tugas berkaitan akademik, seperti membuat tugasan atau pun belajar untuk menghadapi peperiksaan.

Selain dari itu, kekuatan dalaman juga merangkumi dimensi kesedaran kendiri, yang ditakrifkan sebagai memahami diri seseorang. Kesedaran kendiri sangat penting kerana dapat memahami pengaruh pemikiran seseorang terhadap perlakuan, perasaan dan mood serta kekuatan dan cabaran yang ditanggung olehnya. Kesedaran kendiri merupakan kemahiran menghayati pengalaman yang dilalui dengan berkesan dan mengambil iktibar dari pengalaman tersebut.

Akhirnya, bagi dimensi matlamat dan aspirasi, ia merujuk kepada impian, visi dan perancangan seseorang untuk masa hadapannya. Matlamat dan aspirasi yang ada di dalam diri seseorang murid mampu memberi harapan dan jangkaan yang tinggi kepada kehidupannya. Matlamat dan aspirasi merupakan motivasi dalaman yang wujud yang mampu membimbing ke arah pembangunan insan. Faktor ini merupakan aspek penting dalam menentukan jangkaan positif dalam diri murid tersebut bagi kehidupan akan datang.

Pengukuran faktor kekuatan dalaman bagi kajian ini akan mengambil kira semua dimensi yang telah diketengahkan oleh West Ed dan CDE (2000) ini, memandangkan ianya komprehensif dan sesuai untuk konteks kajian yang melibatkan murid sekolah menengah di Malaysia.

\section{Faktor Pelindung}

Faktor seterusnya yang memainkan peranan besar dalam ketahanan diri seseorang individu adalah faktor pelindung. Menurut Scales (2011), faktor pelindung merupakan aset yang tidak ternilai dari pelbagai bentuk seperti pengalaman, peluang, perhubungan, nilai dan kemahiran yang mampu memperbaiki diri serta meningkatkan ketahanan diri individu yang berhadapan dengan kesukaran dalam hidup. Kajian oleh Forrest-Bank, Nicotera, Anthony dan Jenson (2015) ke atas remaja berisiko juga mendapati faktor pelindung berjaya membendung masalah tingkahlaku ke atas murid yang berisiko. Richardson (2002) telah mengutarakan faktor pelindung sebagai faktor yang menyebabkan individu yang dilanda masalah 
atau ancaman di dalam hidup mampu bertahan malah menjadi lebih baik atau lebih kuat. Fungsi faktor pelindung dalam kajian ini dapat dikaitkan dengan tumpuan murid yang tidak terjejas sepanjang proses pembelajaran berlangsung walaupun berhadapan dengan ibu bapa yang bercerai. Ianya selari dengan Rodgers dan Rose (2004) yang menyatakan bahawa murid dari latar belakang ibu bapa yang bercerai biasanya mempunyai ciri personaliti tertentu dan persekitaran yang membantu mereka supaya dapat menyederhanakan kesan dari risiko yang dialami.

Faktor pelindung secara umumnya dapat berfungsi sebagai faktor persekitaran yang menyederhanakan (moderate) atau menjadi perantara (mediator) antara risiko atau ancaman yang dihadapi dengan penyesuaian positif individu terbabit (Masten \& Reed, 2002). Zainal Abidin, Awang-Hashim dan Nordin (2018) mendapati faktor pelindung yang diperolehi daro sokongan. Fungsi faktor pelindung (keprihatinan perhubungan, jangkaan tinggi dan penglibatan yang bermakna) dalam persekitaran sekolah, komuniti, rakan sebaya dan rumah ialah menyederhanakan kesan-kesan negatif yang berlaku apabila individu dilanda masalah atau tekanan dalam hidup. Gambaran yang sama juga diberikan oleh Amato (2000), yang menyifatkan faktor pelindung sebagai 'penyerap hentakan' iaitu yang mampu mengurangkan kesan-kesan negatif hasil dari perceraian.

Tambahan pula, menurut Masten dan Reed (2002), pengaruh faktor pelindung adalah istimewa untuk dikaji kerana walaupun individu mengalami risiko yang sama, hasil atau penyesuaian positif akan berbeza-beza antara individu. Aspek-aspek perbezaan berkaitan faktor dan proses penyesuaian positif telah menarik minat para pengkaji dalam bidang ketahanan diri; iaitu apabila terdapat kelompok individu yang mampu menangani ancaman dan seterusnya berjaya menunjukkan ketahanan diri akademik yang tinggi dengan menunjukkan keputusan akademik yang memuaskan, sedangkan pada masa yang sama terdapat kelompok lain menjadi lemah dan merosot dalam akademik (Masten \& Reed, 2002). Oleh yang demikian, ketahanan diri akademik perlu dilihat sebagai fenomena yang kontinium.

Schoon (2006) menyenaraikan tiga pemboleh ubah utama yang berfungsi sebagai faktor pelindung iaitu sifat individu tersebut, ciri keluarga terutamanya peranan ibu bapa dan aspek sosial seperti 
guru dan persekitaran sekolah. Sifat individu yang mempunyai kepercayaan yang tinggi terhadap diri sendiri, bermotivasi dalam pelajaran serta mempunyai perancangan dan pilihan karier yang lebih baik untuk masa depan. Persekitaran keluarga yang kondusif seperti ibu bapa yang terlibat aktif dengan aktiviti anak-anak mereka di sekolah ataupun bapa yang banyak membantu ibu dengan kerjakerja rumah merupakan antara faktor pelindung yang meningkatkan ketahanan diri akademik murid. Guru yang mampu mengenal pasti keupayaan dan potensi murid akan memupuk penyesuaian positif dalam kalangan murid yang bermasalah. Faktor-faktor yang dikemukakan Schoon (2006) ini dikategorikan sebagai sumber untuk menyokong pembentukan penyesuaian positif dalam diri individu bermasalah. Maka individu yang mempunyai sumber yang lebih banyak atau lebih kuat akan mempunyai ketahanan diri yang lebih baik (Schoon, 2006).

\section{Kerangka Teori Kajian}

Tinjauan literatur seterusnya membincangkan secara ringkas tentang kerangka teori kajian ini. Teori Ekologi Bronfenbrenner diguna pakai bagi menerangkan tentang kewujudan pengaruh faktor persekitaran ke atas ketahanan diri akademik seorang individu khasnya murid dari latar belakang ibu bapa yang bercerai. Kajian awal berkaitan konsep ketahanan diri akademik dilihat hanya berkisar ke atas individu yang terlibat sahaja (Brendtro \& Longhurst, 2005), tetapi secara beransur-ansur, kajian seterusnya mendapati bahawa sumber atau faktor yang meningkatkan ketahanan diri juga melibatkan keluarga, sekolah, dan masyarakat (Brendtro \& Longhurst, 2005).

Institusi keluarga dan sekolah membentuk mikrosistem dan eksosistem memainkan peranan penting membantu dalam proses murid menangani ancaman dan menjadi individu yang berketrampilan terutamanya dalam pencapaian akademik walaupun berhadapan dengan ancaman dalam kehidupan. Kajian mendapati keluarga, sekolah dan masyarakat juga mempengaruhi antara satu sama lain bagi meningkatkan ketahanan diri akademik dan juga berfungsi sebagai faktor pelindung ke atas murid yang terbabit (Brendtro \& Longhurst, 2005).

Dengan mengambil kira faktor individu (yang diterjemahkan sebagai kekuatan dalaman), dan persekitaran (yang diintepretasikan sebagai faktor pelindung), Teori Ekologi Bronfenbrenner dijadikan kerangka teori yang mendokong kajian ini. 


\section{METODOLOGI}

Kajian ini dijalankan di Negeri Kedah, iaitu salah sebuah negeri di Malaysia. Data bilangan murid yang mempunyai latar belakang ibu bapa yang bercerai merupakan data sulit yang sukar diperolehi dari pihak sekolah. Justeru, pengkaji telah menjalankan soal selidik awal dalam kalangan murid Tingkatan 4, iaitu yang berumur 16 tahun di 19 buah sekolah terpilih yang mempunyai kecemerlangan akademik tinggi. Ini adalah bagi mendapatkan senarai murid tingkatan empat yang mempunyai ibubapa bercerai. Seramai 46 orang murid Tingkatan 4 telah dikenal pasti sebagai murid yang mempunyai latar belakang ibu bapa bercerai. Analisis data dibuat secara terperinci bagi mendapatkan profil murid dari segi tahap ketahanan diri, kekuatan dalaman dan faktor pelindung yang ada pada mereka.

Seterusnya, seramai lima orang murid tingkatan empat telah dipilih berdasarkan tahap ketahanan diri dan pencapaian akademik yang paling tinggi. Temu bual dijalankan untuk menyokong persoalan sejauhmanakah pengaruh setiap pemboleh ubah iaitu faktor pelindung dan kekuatan dalaman ke atas ketahanan diri akademik murid yang berasal dari ibu bapa yang bercerai.

\section{Instrumen Kajian Kuantitatif}

Johnson dan Christensen (2008) menyarankan supaya para penyelidik menggunakan instrumen sedia ada dan kukuh yang telah dibina oleh pakar terdahulu sebelum mampu membinanya sendiri. Oleh yang demikian, untuk mengukur faktor pelindung, penyelidik menggunakan Resilience Youth Development Module (RYDM) (WestEd \& CDE, 2000). Modul ini merupakan modul dari California Healthy Kids Survey (CHKS) versi M6 2002 yang telah dibangunkan di bawah kontrak California Department of Education $(C D E)$ oleh West Ed. merupakan agensi penyelidikan dan pembangunan yang bukan berasaskan keuntungan di Amerika Syarikat. Kebenaran bertulis untuk menggunakan RYDM sebagai soal selidik telah diperoleh dari agensi tersebut. Faktor pelindung yang diukur termasuk keprihatinan perhubungan, jangkaan tinggi dan penglibatan bermakna dalam persekitaran sekolah, rumah, komuniti dan rakan sebaya.

Ketahanan diri murid diukur menggunakan Skala Ketahanan Diri (SKD) yang telah dibangunkan oleh Wagnild dan Young (1993). 
RYDM (WestEd \& CDE, 2000) juga digunakan untuk mengukur kekuatan dalaman.

\section{Instrumen Kajian Kualitatif}

Temu bual secara separa berstruktur telah dijalankan untuk mendapat maklumat yang lebih mendalam dan bermakna berkaitan dengan ketahanan diri, faktor pelindung dan kekuatan dalaman ke atas murid dari latar belakang ibu bapa yang bercerai. Temu bual dijalankan mengikut garis panduan temu bual yang disediakan berdasarkan persoalan dan objektif kajian dalam kajian ini. Soalan-soalan disediakan sebagai panduan semasa sesi temu bual dijalankan, walau bagaimanapun sesi temu bual dijalankan secara separa berstruktur kerana menurut Romm (2002), temu bual sebegini lebih bersesuaian kerana mampu menimbulkan suasana selesa dan mesra antara responden dan pengkaji. Walau pun keadaan ini akan mengurangkan kawalan pengkaji ke atas butiran perbincangan, tetapi pengkaji berupaya memperoleh jumlah data yang banyak (Smith \& Osborn, 2003). Menurut Smith dan Osborn (2007) juga, kawalan temu bual sebenarnya masih bergantung kepada kreativiti pengkaji untuk mengawal perbualan supaya sentiasa berkisar dengan persoalan dan objektif kajian. Soalan-soalan utama temu bual disediakan bagi memastikan sesi temu bual berjalan dengan lebih terkawal. Untuk kajian ini soalan-soalan utama dibahagikan kepada empat bahagian iaitu demografi, ketahanan diri, faktor pelindung dan kekuatan dalaman.

\section{Prosedur Pengumpulan Data}

Kajian dimulakan dengan menjalankan kajian rintis ke atas 30 responden kajian yang bukan merupakan responden populasi kajian tetapi responden lain yang mempunyai ciri-ciri yang sama dengan ciri-ciri responden kajian, iaitu dari latar belakang ibu bapa bercerai (Gay et al.; 2006, Chua Yan Piaw; 2011). Seterusnya soal selidik diedarkan sendiri oleh penyelidik kepada murid di sekolah-sekolah terpilih, dengan kerjasama guru bagi mentadbir soal selidik tersebut. Penyelidik membuat temu janji susulan untuk mengutip sendiri soal selidik yang telah siap dijawab.

Untuk kajian sebenar, soal selidik telah diedarkan kepada seramai 46 orang murid yang telah dikenal pasti dari latar belakang ibu bapa 
yang bercerai. Kebenaran pihak pentadbir sekolah diperoleh sekali lagi ke atas lima orang murid untuk ditemu bual.

\section{Prosedur Analisis Data Kuantitatif}

Analisis kuantitatif yang digunakan dalam kajian ini adalah bagi mendapatkan profil responden, terutamanya untuk mengenal pasti tahap ketahanan diri, kekuatan dalaman dan faktor pelindung dalam kalangan murid yang mempunyai ibu bapa bercerai. Analisis ini dijalankan dengan menggunakan perisian SPSS versi 22.

\section{Prosedur Analisis Data Kualitatif}

Kaedah pengumpulan data melalui temubual telah membantu pengkaji mencari serta menilai maklumat untuk membuktikan sesuatu tema. Aspek ketelusan (trustworthiness) dipraktikkan demi memastikan kesahan dan kebolehpercayaan instrumen kajian kualitatif yang digunakan. Antara kelebihan kaedah kualitatif ialah kemampuan menjawab persoalan yang mungkin tidak dapat dijelaskan melalui data kuantitatif (Richards \& Morse, 2012). Kaedah temu bual dilakukan ke atas lima orang murid tingkatan empat yang terpilih. Kaedah kualitatif digunakan dalam kajian ini untuk memperoleh pemahaman yang lebih jelas dan mendalam ke atas pengaruh faktor pelindung dan kekuatan dalaman terhadap ketahanan diri akademik murid yang berasal dari ibu bapa yang bercerai. Rakaman dan catatan temu bual didengar semula dan ditranskrip secara bertulis dengan sistematik. Langkah seterusnya ialah pengkaji berulang kali membaca hasil dokumentasi untuk memastikan maksud yang ingin disampaikan oleh responden dan pengkaji tidak bercanggah. Rujukan semula dilakukan ke atas hasil rakaman dan juga catatan semasa temu bual sekiranya pengkaji mendapati terdapat bahagian dalam dokumentasi yang agak kabur dari segi maksud dan kefahaman. Langkah ketiga ialah mengenal pasti data yang tidak berkaitan dan mengasingkan data tersebut. Seterusnya data yang telah diasingkan akan dikategorikan mengikut tema yang ditetapkan oleh pengkaji. Langkah terakhir ialah pengkaji menilai dan mendefinisikan semula data yang telah dikategorikan.

Kaedah triangulasi, 'memberchecking', 'debriefing' dan pengauditan telah digunakan untuk memastikan kredibiliti instrumen yang digunakan. Kaedah 'member checking' iaitu dengan meminta peserta 
kajian menyemak semula dapatan yang disediakan pengkaji dan membuat pengesahan atau pembetulan (Creswell, 2011). Pengkaji telah meminta responden untuk menyemak transkrip yang dihasilkan seterusnya membuat pengesahan ke atas interpretasi maklumat yang telah ditranskrip. Kaedah 'member checking' menerusi sesi pembentangan (debriefing) dapatan kajian khususnya tema-tema yang timbul turut dijalankan melibatkan beberapa rakan profesional untuk menyemak tema-tema yang timbul daripada analisis tematik. Perbincangan dengan rakan profesional bukan sahaja mampu membantu pengkaji menilai kembali interpretasi yang telah dibuat tetapi dapat mengelakkan bias atau kecenderungan, seterusnya meningkatkan kredibiliti kajian ini (Rohani Arbaar, 2014; Burnard, Gill, Stewart, Treasure dan Chadwick, 2008; Shenton, 2004). Beberapa pembetulan dari segi tema yang timbul daripada proses metasintesis dapatan kajian telah dilakukan hasil daripada proses perbincangan tersebut.

\section{DAPATAN KAJIAN}

\section{Profil Responden Kajian}

Profil responden ini adalah untuk meneliti ciri-ciri demografi murid berlatar belakang ibu bapa bercerai.

Jadual 1

Demografi Responden

\begin{tabular}{llll}
\hline Demografi Responden & & $\mathrm{N}$ & $\%$ \\
\hline Jantina & Lelaki & 18 & 39 \\
& Perempuan & 28 & 61 \\
\hline Tinggal dengan & Ibu & 31 & 68 \\
& Bapa & 12 & 26 \\
& Penjaga & 1 & 2 \\
& Ibu \& bapa tiri & 1 & 2 \\
& Bapa \& ibu tiri & 1 & 2 \\
\hline Bilangan adik beradik & $1-3$ orang & 24 & 52 \\
& $4-6$ orang & 16 & 35 \\
& $7-9$ orang & 4 & 9 \\
& $10-12$ orang & 2 & 4 \\
\hline
\end{tabular}


Tahap Faktor Pelindung, Kekuatan Dalaman dan Ketahanan Diri Akademik Murid

Keputusan analisis min dan sisihan piawai bagi setiap faktor yang dikaji dalam kajian ini adalah seperti yang tertera di Jadual 2.

Jadual 2

Analisis Tahap Pemboleh Ubah Kajian bagi Responden Ibu Bapa Bercerai

\begin{tabular}{|c|c|c|c|c|c|c|c|c|c|}
\hline \multirow[t]{2}{*}{ Pemboleh ubah } & \multicolumn{2}{|c|}{$\begin{array}{c}\text { Tahap } \\
\text { Rendah }\end{array}$} & \multicolumn{2}{|c|}{$\begin{array}{c}\text { Tahap } \\
\text { Sederhana }\end{array}$} & \multicolumn{2}{|c|}{$\begin{array}{l}\text { Tahap } \\
\text { Tinggi }\end{array}$} & \multirow[t]{2}{*}{ Min } & \multirow[t]{2}{*}{ SP } & \multirow[t]{2}{*}{$\begin{array}{l}\text { Tahap } \\
\text { purata }\end{array}$} \\
\hline & $\mathrm{N}$ & $\%$ & $\mathrm{~N}$ & $\%$ & $\mathrm{~N}$ & $\%$ & & & \\
\hline $\begin{array}{l}\text { Faktor } \\
\text { Pelindung }\end{array}$ & 0 & 0 & 4 & 8.7 & 42 & 91.3 & 3.06 & 0.35 & Tinggi \\
\hline $\begin{array}{l}\text { Keperihatinan } \\
\text { perhubungan }\end{array}$ & 0 & 0 & 6 & 13.0 & 40 & 87.0 & 3.00 & 0.38 & Sederhana \\
\hline $\begin{array}{l}\text { Jangkaan } \\
\text { tinggi }\end{array}$ & 0 & 0 & 1 & 2.2 & 45 & 97.8 & 3.38 & 0.36 & Tinggi \\
\hline $\begin{array}{l}\text { Penglibatan } \\
\text { bermakna }\end{array}$ & 0 & 0 & 16 & 34.8 & 30 & 65.2 & 2.96 & 0.49 & Sederhana \\
\hline $\begin{array}{l}\text { Kekuatan } \\
\text { Dalaman }\end{array}$ & 0 & 0 & 4 & 8.7 & 42 & 91.3 & 3.20 & 0.39 & Tinggi \\
\hline $\begin{array}{l}\text { Kemahiran } \\
\text { menyelesaikan } \\
\text { masalah }\end{array}$ & 0 & 0 & 9 & 19.6 & 37 & 80.4 & 3.16 & 0.53 & Tinggi \\
\hline $\begin{array}{l}\text { Kesedaran } \\
\text { kendiri }\end{array}$ & 0 & 0 & 4 & 8.7 & 42 & 91.3 & 3.31 & 0.46 & Tinggi \\
\hline Efikasi Kendiri & 0 & 0 & 8 & 17.4 & 38 & 82.6 & 3.11 & 0.50 & Tinggi \\
\hline Ketahanan Diri & 0 & 0 & 15 & 32.6 & 31 & 67.4 & 5.06 & 0.99 & Tinggi \\
\hline $\begin{array}{l}\text { Mempunyai } \\
\text { tujuan hidup }\end{array}$ & 0 & 0 & 10 & 21.7 & 36 & 78.3 & 5.13 & 0.97 & Tinggi \\
\hline Ketabahan & 0 & 0 & 14 & 30.4 & 32 & 69.6 & 5.16 & 1.04 & Tinggi \\
\hline $\begin{array}{l}\text { Percaya pada } \\
\text { diri sendiri }\end{array}$ & 1 & 2.2 & 20 & 43.5 & 25 & 54.3 & 4.90 & 1.24 & Tinggi \\
\hline Redha & 1 & 2.2 & 21 & 45.7 & 24 & 52.2 & 4.88 & 1.30 & Tinggi \\
\hline Bersendirian & 0 & 0 & 14 & 30.4 & 32 & 69.6 & 5.21 & 1.14 & Tinggi \\
\hline
\end{tabular}


Jadual 2 di atas memperlihatkan tahap faktor pelindung dalam kalangan 46 orang responden bagi status ibu bapa bercerai adalah pada tahap sederhana seramai 4 orang $(8.7 \%)$ dan pada tahap tinggi seramai 42 orang (91.3\%). Dapatan ini menunjukkan tahap pemboleh ubah faktor pelindung secara keseluruhannya berada pada tahap tinggi dengan nilai $(\mathrm{M}=3.06 ; \mathrm{SP}=0.35)$.

Dapatan ke atas pemboleh ubah kekuatan dalaman memperlihatkan seramai 4 orang $(8.7 \%)$ berada pada tahap sederhana dan responden yang berada tahap tinggi adalah seramai 42 orang (91.3\%). Oleh itu, tahap pemboleh ubah kekuatan dalaman secara keseluruhannya adalah pada tahap tinggi $(\mathrm{M}=3.20 ; \mathrm{SP}=0.39)$.

Seterusnya bagi pemboleh ubah ketahanan diri bagi 46 responden berstatus ibu bapa bercerai, seramai 15 orang responden (32.6\%) berada pada tahap sederhana mana kala seramai 31 orang $(67.4 \%)$ berada pada tahap tinggi. Oleh itu, dapatan jelas menunjukkan bahawa pemboleh ubah ketahanan diri secara keseluruhannya berada pada tahap tinggi $(\mathrm{M}=5.06 ; \mathrm{SP}=0.99)$.

Untuk meneroka dengan lebih mendalam pengaruh faktor pelindung dan kekuatan dalaman terhadap ketahanan diri, sesi temu bual telah dijalankan ke atas lima responden yang terpilih. Setiap responden dilabel sebagai responden A, B, C, D dan E. Hasil temu bual yang dijalankan telah membuktikan pengaruh dan peranan yang dimainkan oleh kedua-dua pemboleh ubah bebas iaitu faktor pelindung dan kekuatan dalaman dalam meningkatkan ketahanan diri akademik murid. Temu bual yang dijalankan ke atas kelima-lima responden mendapati faktor pelindung iaitu elemen dan unsur yang terdapat dalam persekitaran kehidupan mereka memang memainkan peranan penting bagi meningkatkan ketahanan diri akademik apabila berhadapan dengan perceraian kedua ibu bapa.

Lima dimensi utama yang dibincangkan berkaitan peningkatan ketahanan diri yang disebabkan oleh pengaruh faktor pelindung dan kekuatan dalaman ialah:

i. Mempunyai tujuan hidup (purposeful life)

Mempunyai tujuan hidup (purposeful life) merupakan ciri yang paling penting apabila membincangkan mengenai ketahanan diri. 
Temu bual yang dijalankan bertujuan untuk mengenal pasti ciriciri yang terdapat di dalam dimensi 'mempunyai tujuan hidup' dan pengaruh dari faktor pelindung dan juga kekuatan dalaman. Di antaranya ialah mengenal pasti responden yang dapat mengekalkan minat terhadap pembelajaran di sekolah, merasa bangga apabila berjaya mencapai keputusan yang memuaskan dan juga responden yang merasakan hidupnya sentiasa mempunyai makna.

Responden A masih mampu mengekalkan minat dalam pelajaran walau pun berada di dalam keluarga yang berpisah. Hal ini menggambarkan beliau seorang yang mempunyai ketahanan diri akademik yang tinggi. Hasil temu bual membuktikan sokongan yang diterima terutamanya dari keluarga, rakan-rakan dan para guru merupakan elemen yang paling penting membantu responden untuk sentiasa mempunyai tujuan hidup.

\section{ii. Ketabahan (perseverance)}

Ketabahan (perseverance) iaitu perasaan tekad untuk menempuh segala kesulitan, halangan dan kesedihan (Wagnild \& Young, 2008). Aspek yang dikenal pasti bagi dimensi ketabahan ialah sama ada responden mengikut perancangan pencapaian akademik yang telah dibuat, responden mempunyai keazaman dan disiplin yang tinggi untuk berjaya dalam pelajaran dan juga responden sentiasa bertenaga untuk menumpukan perhatian dalam bidang akademik.

Hasil temu bual bersama Responden A menunjukkan beliau mampu mengikut perancangan yang dibuat dan pada masa yang sama mempunyai disiplin belajar yang tinggi dan sentiasa berusaha bersungguh-sungguh untuk mencapai segala yang dirancang.

\section{iii. Redha (equanimity)}

Redha (equanimity) bermaksud mempunyai kehidupan yang seimbang dan harmoni. Dalam konteks ketahanan diri akademik, individu yang mempunyai sifat redha adalah individu yang dapat menenangkan diri dan bersikap terbuka sekiranya timbul masalah dengan pembelajaran. Individu ini juga mampu mengharungi kehidupan sebagai seorang murid dengan harmoni tanpa kerisauan yang tinggi dan tidak akan terus memikirkan masalah yang diluar kemampuannya untuk diselesaikan sendiri. 
Apabila disoal berkaitan dengan tindakan yang diambil sekiranya berhadapan dengan perselisihan faham antara ahli keluarga, responden A memberikan jawapan yang membuktikan beliau adalah seorang yang mempunyai ketahanan diri akademik yang tinggi, kerana masih mampu menumpukan perhatian dalam pelajaran walaupun dalam keadaan tertekan.

\section{iv. Percaya pada diri (self reliance)}

Percaya pada diri (self reliance) iaitu kepercayaan seseorang individu ke atas keupayaan dan kekurangan yang terdapat dalam diri sendiri. Bagi dimensi 'percaya pada diri' antara aspek yang dikenal pasti semasa temu bual ialah responden memberi maklum balas bahawa mereka mampu untuk menguruskan bebanan belajar dengan pelbagai cara dan juga akan sentiasa berjaya mencari jalan keluar dari situasi sukar tersebut.

Hasil temu bual dengan Responden A juga membuktikan bahawa responden mampu mengharungi masa sukar akibat penceraian ibu bapa dan meneruskan kehidupan persekolahan seperti biasa. Aspek ini merupakan antara ciri individu yang percaya pada diri sendiri iaitu mempunyai ketahanan diri akademik yang tinggi. Beliau telah berjaya menggunakan strategi belajar yang berkesan seterusnya menunjukkan keputusan peperiksaan yang kekal cemerlang walaupun menghadapi konflik ibu bapa.

\section{v. Bersendirian (existential aloneness)}

Bersendirian (existential aloneness) yang dimaksudkan ialah seseorang yang mempunyai ketahanan diri akademik yang tinggi mampu 'hidup dalam dunianya sendiri'. Individu yang mempunyai ketahanan diri akademik yang tinggi adalah individu yang berkeyakinan diri, boleh berdikari dan tidak bergantung pada orang lain ketika mengharungi masa-masa yang sukar.

Meneliti hasil temu bual bersama responden $\mathrm{D}$ mendapati responden merupakan seorang yang sangat berdikari dan mampu membuat keputusan sendiri ke atas pelbagai perkara terutamanya dalam bidang pelajaran. Sebagai contoh, ketika disoal berkaitan pemilihan mata pelajaran sama ada Sains atau Sastera, beliau memaklumkan bahawa pemilihan dibuat sendiri tanpa dipengaruhi oleh orang 
lain. Begitu juga, sekiranya menghadapi masalah beliau akan menyelesaikan sendiri.

\section{PERBINCANGAN DAN KESIMPULAN}

Kajian yang dijalankan bertujuan untuk mengenal pasti pelbagai jenis maklumat dan pengetahuan berkaitan pengaruh faktor pelindung dan kekuatan dalaman ke atas ketahanan diri akademik murid berasal dari ibu bapa yang bercerai. Di samping itu kajian ini juga bertujuan untuk mengenal pasti dimensi faktor pelindung dan kekuatan dalaman yang menjadi peramal yang berkesan bagi menentukan ketahanan diri akademik murid dari latar belakang ibu bapa yang bercerai. Melalui kajian kualitatif pula, penyelidik meneroka dengan lebih terperinci peranan faktor pelindung dan kekuatan dalaman dalam meningkatkan ketahanan diri akademik murid dari latar belakang ibu bapa yang bercerai.

Teori utama yang digunakan untuk menerangkan pengaruh faktor pelindung dan kekuatan dalaman bagi meningkat ketahanan diri ialah Teori Ekologi Bronfenbrenner (Bronfenbrenner, 1979). Perbincangan berkaitan dengan ketahanan diri perlu mengaitkan antara dua konstruk utama iaitu pengalaman atau pendedahan kepada keadaan yang sukar manakala konstruk kedua ialah proses penyesuaian sikap yang positif, contohnya kemampuan untuk menangani tekanan ataupun mempunyai kemahiran penyelesaian masalah yang tinggi. Berdasarkan Model Ketahanan Diri Richardson (2002) juga, untuk mempunyai ketahanan diri memerlukan dua perkara iaitu gangguan atau tekanan dalam hidup dan juga penyesuaian positif selepas melalui gangguan atau tekanan tersebut. Sehubungan dengan itu, fokus utama dalam kajian ini adalah untuk mengkaji fungsi serta pengaruh faktor pelindung dan kekuatan dalaman yang meningkatkan ketahanan diri akademik murid walaupun berada di dalam keluarga yang bercerai.

Dapatan kajian telah membuktikan bahawa faktor pelindung iaitu sokongan dari ahli keluarga, guru-guru dan kawan-kawan merupakan penyumbang yang mampu meningkatkan ketahanan diri akademik murid dari latar belakang ibu bapa yang bercerai. Dapatan temu bual ke atas kelima-lima orang responden yang mempunyai latar belakang ibu bapa bercerai menunjukkan bahawa faktor pelindung 
dan kekuatan dalaman berperanan meningkatkan ketahanan diri akademik murid yang terlibat.

Kajian ini memberi sokongan empirikal bagi Teori Ekologi Bronfenbrenner, sebagai teori yang dapat mendokong keseluruhan kajian yang melibatkan faktor individu dan faktor persekitaran yang berkait rapat dengan ketahanan diri akademik murid. Kajian Ungar $(2012$; 2013) yang menggunakan pendekatan ekologi juga bersetuju bahawa interaksi yang berlaku antara individu dan persekitaran sosial menyumbang kepada peningkatan ketahanan diri. Secara umum, teori ini dapat digunakan untuk menerangkan pengaruh atau hubungan antara individu dengan sistem persekitarannya dalam konteks meningkatkan ketahanan diri akademik murid tersebut. Berdasarkan hasil kajian ini, dapat disimpulkan bahawa penglibatan bermakna murid dengan persekitarannya di sekolah terutamanya, jangkaan tinggi para guru ke atas kemampuan murid tersebut dan keprihatinan perhubungan antara murid dan guru merupakan dimensi penting dalam pemboleh ubah faktor pelindung bagi meningkatkan ketahanan diri akademik dalam kalangan murid yang mempunyai ibu bapa bercerai.

Hasil kajian ini juga dapat mengukuhkan lagi Model Ketahanan Diri Richardson (2002). Berdasarkan model ini, murid yang mempunyai pelbagai sumber faktor pelindung cenderung untuk mempunyai ketahanan diri yang lebih tinggi dalam akademik, kerana faktorfaktor ini melindungi murid daripada kesan faktor-faktor risiko (Werner, 2000). Walaupun kekuatan dalaman diri rendah namun murid boleh berjaya dalam akademik jika keluarga atau sekolah menyediakan persekitaran yang kondusif. Selain itu, menurut Yahya, Latif, Shahrin Hahim dan Yusof Boon (2006) faktor persekitaran memberi pengaruh besar dalam kehidupan murid. Walaupun keputusan menunjukkan kekuatan dalaman kurang memberi pengaruh terhadap tahap ketahanan diri akademik murid tetapi sedikit sebanyak tetap menyumbang untuk meningkatkan potensi akademik murid berkenaan. Perkara ini turut dijelaskan oleh Imam Al-Ghazali (1995) iaitu menekankan unsur ketahanan diri manusia bermula dari dalam diri mereka sendiri. Namun begitu, perlu ada faktor-faktor pelindung dalaman dan luaran yang bekerjasama untuk memupuk ketahanan diri akademik setiap individu.

Sebagai kesimpulan, dapatan kajian membuktikan faktor pelindung iaitu keprihatinan perhubungan, jangkaan tinggi dan penglibatan 
bermakna merupakan dimensi yang dapat meningkatkan ketahanan diri akademik murid yang berasal dari ibu bapa yang bercerai.

Jarak pemisahan yang wujud secara fizikal didapati tidak menjadi penghalang kepada ibu atau bapa yang tidak tinggal bersekali dengan anak-anak sekiranya medium seperti telefon dan internet digunakan sebaik mungkin untuk tujuan komunikasi. Keprihatinan perhubungan yang dapat dirasakan oleh mereka mampu meningkatkan ketahanan diri akademik dalam kalangan mereka. Jangkaan tinggi yang ditunjukkan, sokongan yang diberikan oleh ibu dan bapa serta persekitaran yang kondusif mampu meningkatkan ketahanan diri akademik murid dari latar belakang ibu bapa yang bercerai.

\section{RUJUKAN}

Abdullah, M. C., Kong, L. L., \& Talib, A. R., (2014). Perceived social support as predictor of university adjustment and academic achievement amongst first year undergraduates in a malaysian public university. Malaysian Journal of Learning and Instruction, 11, 59-73

Abu Bakar, A., Jamaludin, S., \& Darusalam, G., (2010). Resiliency among secondary school students in Malaysia: assessment of the measurement model. The International Journal of Educational and Psychological Assessment, 4, 68-76.

Alvord, M. K., \& Grados, J. J. (2005). Enhancing resilience in children: A proactive approach. Professional psychology: Research and practice, 36(3), 238.

Amato, P., \& Sobolewski, J. (2001). The effects of divorce and marital discord on adult children's psychosocial well-being. American Sociological Review, 66, 900 - 921.

Amato, P. R., \& Keith, B. (1991), Parental divorce and the wellbeing of children: A meta-analysis. Psychological Bulletin, 110, 26-46.

Amato, P. R., \& Previti, D. (2003). People's reasons for divorcing: Gender, social class, the life course, and adjustment. Journal of Family Issues 24(5):602-26.

Baker, E.T., Wang, M.C., \& Walberg, H.J. (1994). The effects of inclusion on learning. Educational Leadership, 52(4), 3-35.

Brendtro, L.K., \& Longhurst, J.E. (2005, Spring). The resilient brain. Reclaiming Children and Youth, 14(1), 52-60. 
Snyder, C.R., Lopez, S. J., (2007). Positive Psychology: The scientific and practical exploration of human strengths. Sage Publications Ltd.CA: Wadsworth.

Cabness, J. L. (2003). Psychosocial resilience, depression and subjective well-being in long term care. Dissertation Abstracts International, 63(12-A), 4473, US: University Microfilms International.

Chen, J. \& George, R. A. (2005). Cultivating resilience in children from divorced families. The Family Journal: Counseling and Therapy for Couples and Families, 13, 452-455. Children 's closeness to grandparents following parental divorce and remarriage.

Chua, Y. P. (2011). Kaedah dan statistik penyelidikan. Kuala Lumpur: Mc Graw-Hill.

Chuan, C. L. (2006). Sample size estimation using Krejcie and Morgan and Cohen statistical power analysis: A comparison. Jurnal Penyelidikan IPBL, 7, 78-86.

Creswell J.W. (2011). Educational research: planning, conducting, and evaluating quantitative and qualitative research. Edinburgh Gate: Pearson Education Limited.

Deci, E. L., \& Ryan, R. M. (2008). Self-determination theory: A macrotheory of human motivation, development, and health. Canadian psychology/Psychologie Canadienne, 49(3), 182.

Eggen, P., \& Kauchak, D. (2007). Group and individual differences. Educational Psychology: Windows on Classrooms (7th ed., pp. 103-116). Pearson: Merrill Prentice Hall.

Gay, L. M. G. \& Airasian, P. (2006). Educational research: Competencies for analysis and application, 8(1).

Greeff, A. P., \& Van Der M, S. (2004). Variables associated with resilience in divorced families. Social Indicators Research, $68,59-75$.

Greene, R. \& Conrad, A. P. (2002). Basic assumptions and terms. In R. Greene (Ed.), Resiliency: An integrated approach to practice, policy, and research. (pp.29-62). Washington, DC: NASW Press.

Hetherington, E. M., \& Kelly, J. (2003). For better or for worse: Divorce reconsidered. WW Norton \& Company.

Jenson, J. M., \& Fraser, M. W. (2006). A risk and resilience framework for child, youth, and family policy. Social policy for children \& families: A risk and resilience perspective, 118. 
Johnson, B., \& Christensen, L. (2008). Educational research: Quantitative, qualitative, and mixed approaches. Sage.

Martin, A.J, \& Marsh, H.W (2009). Academic resilience and academic buoyancy: multidimensional and hierarchical conceptual framing of causes, correlates and cognate constructs. Oxford Review of Education, 35(3), 353-370.

Masten, A. S. \& Reed, M. J. (2002). Resilience in development. In C. R. Snyder \& S. J. Lopez (Eds.), The handbook of positive psychology (pp. 74-88). Oxford University Press.

Masten, A. S. (2001). Ordinary magic: resilience processes in development. American Psychologist, 56(3), 227-238.

Merriam, S. B. (1998). Qualitative research and case study applications in education. revised and expanded from" Case Study Research in Education.". Jossey-Bass Publishers, 350 Sansome St, San Francisco, CA 94104.

Patterson, J. M. (2002). Integrating family resilience and family stress theory. Journal of Marriage and Family, 64, 349-360.

Richardson, G. E. (2002). The metatheory of resilience and resiliency. Journal of Clinical Psychology, 58, 307-321.

Rodgers, K. B., \& Rose, H. A. (2002). Risk and resiliency factors among adolescents who experience marital transitions. Journal of Marriage and the Family, 64, 1024-1037.

Romm, N. (2002). A trusting constructivist approach to systemic inquiry: Exploring accountability. Systems Research and Behavioral Science, 19(5), 455-467.

Sameroff, A. (2006). The promotion of resilience in the face of adversity. In A. Clarke-Stewart \& J. Dunn (Eds.) Families count: Effects on child and adolescent development. London: Cambridge University Press.

Sanders, M. G., \& Jordan, W. J. (2000). Student-teacher relations and academic achievement in high school. Schooling students placed at risk: Research, policy, and practice in the education of poor and minority adolescents, 65-82.

Schoon, I. (2006). Risk and resilience: Adaptations in changing time. Cambridge University.

Smith-Osborne, A. (2007). Life span and resiliency theory: A critical review. Advances in social work, 8(1), 152-168.

Ungar, M. (2005). Pathways to resilience among children in child welfare, corrections, mental health, and educational settings: Navigation and negotiation. Child and Youth Care Forum, $34,423-444$ 
Wagnild, G., \& Young, H. (1993). Development and psychometric. Journal of Nursing measurement, 1(2), 165-178.

Wang, M.C., Haertel, G. D., \& Walberg, H. J. (1994). Educational resilience in inner-city schools. In M.C. Wang \& E.W. Gordon (Eds.), Educational resilience in inner-city America: Challenges and prospects. (pp. 45-72). Hillsdale, NJ: Lawrence Erlbaum Associates.

Waxman, H. C., Padrón, Y. N., \& Garcia, A. (2007). Educational issues and effective practices for Hispanic students. In S. J. Paik \& H. J. Walberg (Eds.). Narrowing the achievement gap: Strategies for educating Latino, Black and Asian students (pp. 131-151). New York: Springer.

Werner, E. E., \& Smith, R. S. (2001). Journeys from childhood to midlife: risk, resilience and recovery. New York: Cornell University Press.

WestEd, \& CDE. (2007). Resilience and Youth Development Module \& handbook. Retrieved from http://www.wested.org/ hks

Yahaya, A., \& Latif, J. S., Hashim, N. \& Boon, Y., (2006). Psikologi sosial alam remaja. PTS Media Group.

Zainal Abidin, Y., Awang Hashim. R., \& Nordin, H., (2018). The life story of a resilient underprivileged youth: motivation to learn soft skills. Malaysian Journal of Learning and Instruction, 15 (1), 57-81. 